\title{
Biological aspects of Eriopis connexa (Germar) (Coleoptera: Coccinellidae) fed on different insect pests of maize (Zea mays L.) and sorghum [Sorghum bicolor L. (Moench.)]
}

\author{
Silva, RB., ${ }^{a, b *}$, Cruz, I. ${ }^{b}$, Zanuncio, JC. ${ }^{a}$, Figueiredo, MLC. ${ }^{b}$, \\ Canevari, GC. ${ }^{a}$, Pereira, $A G .^{c}$ and Serrão, JE. ${ }^{d}$ \\ aPrograma de Pós-graduação em Entomologia, Departamento de Biologia Animal, \\ Universidade Federal de Viçosa - UFV, CEP 36571-000, Viçosa, MG, Brazil \\ 'Laboratório de Criação de Insetos - LACRI, Embrapa Milho e Sorgo, CP 151, CEP 35700-970, Sete Lagoas, MG, Brazil \\ 'Programa de Pós-graduação em Ecologia e Recursos Naturais, Departamento de Ecologia e Biologia Evolutiva - DEBE, \\ Universidade Federal de São Carlos - UFSCar, CP 676, CEP 13565-905, São Carlos, SP, Brazil \\ dPrograma de Pós-graduação em Entomologia, Departamento de Biologia Geral, \\ Universidade Federal de Viçosa - UFV, CEP 36571-000, Viçosa, MG, Brazil \\ *e-mail: rafaelentomologia@yahoo.com.br
}

Received April 2, 2012 - Accepted July 10, 2012 - Distributed May 31, 2013

\begin{abstract}
Eriopis connexa (Germar) (Coleoptera: Coccinellidae) occurs in several countries of South America and its mass rearing is important for biological control programmes. This work evaluated biological aspects of E. connexa larva fed on eggs of Anagasta kuehniella (Zeller) (Lepidoptera: Pyralidae) and Spodoptera frugiperda (J. E. Smith) (Lepidoptera: Noctuidae) frozen for one day, fresh eggs of Diatraea saccharalis (Fabricius) (Lepidoptera: Pyralidae), S. frugiperda newly-hatched caterpillars, nymphs of Rhopalosiphum maidis (Fitch) and Schizaphis graminum (Rondani) (Hemiptera: Aphididae). Duration of larva, pupa and larva to adult stages differed among prey offered, whereas the prepupa stage was similar. Larva, pupa, prepupa and larva to adult viabilities were equal or major of $87.5 \%$ in all prey, except for larva fed on newly-hatched larvae of S. frugiperda. Eriopis connexa has good adaptation to different prey corroborating its polyphagous feeding habit, which evidences the potential of this natural enemy for controlling corn and sorghum pests.

Keywords: Anagasta kuehniella, Diatraea saccharalis, Rhopalosiphum maidis, Schizaphis graminum, Spodoptera frugiperda.

\section{Aspectos biológicos de Eriopis connexa (Germar) (Coleoptera: Coccinellidae) alimentada com diferentes insetos-praga de milho (Zea mays L.) e sorgo [Sorghum bicolor L. (Moench.)]}

\begin{abstract}
Resumo
Eriopis connexa (Germar) (Coleoptera: Coccinellidae) ocorre em vários países da América do Sul e sua criação massal é importante para programas de controle biológico. Este trabalho avaliou os aspectos biológicos de larvas de E. connexa alimentadas com ovos de Anagasta kuehniella (Zeller) (Lepidoptera: Pyralidae) e de Spodoptera frugiperda (J. E. Smith) (Lepidoptera: Noctuidae) congelados por um dia, ovos frescos de Diatraea saccharalis (Fabricius) (Lepidoptera: Pyralidae), lagartas de S. frugiperda recém-eclodidas, ninfas de Rhopalosiphum maidis (Fitch) e Schizaphis graminum (Rondani) (Hemiptera: Aphididae). A duração da fase larval, pupal e de larva a adulto diferiu entre as presas oferecidas; entretanto, a fase de pré-pupa foi semelhante. A viabilidade larval, pré-pupal, pupal e de adultos foi maior ou igual a 87,5\% em todas as presas, com exceção para larvas alimentadas com lagartas recém-eclodidas de $S$. frugiperda. Eriopis connexa tem boa adaptação a diferentes presas, corroborando seu hábito alimentar polífago, o que evidencia o potencial desse inimigo natural para o controle de pragas de milho e sorgo.
\end{abstract}

Palavras-chave: Anagasta kuehniella, Diatraea saccharalis, Rhopalosiphum maidis, Schizaphis graminum, Spodoptera frugiperda. 


\section{Introduction}

Demand for maize, Zea mays L. and sorghum, Sorghum bicolor (L.) Moench (Poales: Poaceae) has increased their cultivated area and, consequently, problems with insect pests in these crops (Sertkaya et al., 2004; Figueiredo et al., 2006a, b; Cruz et al., 2011).

Aphidophagous Coccinellidae has better development when fed on aphids than with other prey, however colonies of these prey represent ephemeral resources, which can be numerous, but for short periods (Michaud and Jyoti, 2007). Larvae of these predators may complete their development with prey that are not aphids but this is poorly studied, although eggs of Coleoptera and Lepidoptera have been used as alternative prey for them (Silva et al., 2009, 2010, 2012).

Polyphagous feeding habits of Eriopis connexa (Germar) (Coleoptera: Coccinellidae) have been reported (Miller and Paustian, 1992; Miller, 1995; Sarmento et al., 2004, 2007; Silva et al., 2009), suggesting that this predator can feed on a wide number of insect pests of corn and sorghum, but food availability and sustainability are fundamental for establishing a species in a new area (Eubanks and Denno, 2000; Roger et al., 2000; Soares et al., 2004; 2005; Berkvens et al., 2008).

The aim of this study was to evaluate biological aspects of E. connexa fed on different insect pests of maize and sorghum and to contribute to using this predator in biological control programmes.

\section{Material and Methods}

The experiment was conducted in the Laboratory of Insect Breeding (LACRI) of the "Empresa Brasileira de Pesquisa Agropecuária (Embrapa Milho e Sorgo)" in Sete Lagoas, Minas Gerais State, Brazil at $25 \pm 1{ }^{\circ} \mathrm{C}, 12 \mathrm{~h}$ photophase and $70 \pm 10 \%$ relative humidity.

Experimental design was in completely randomised blocks with six treatments (Table 1), established from prey type (Table 2) and with four replications, each one with 10 E. connexa larvae, except for the treatment with nymphs of Rhopalosiphum maidis (Fitch) (Hemiptera: Aphididae), which had five E. connexa larvae per replication.

Eriopis connexa larvae were obtained from the laboratory colony where its adults are fed on Anagasta kuehniella (Zeller) (Lepidoptera: Pyralidae) eggs frozen for one week plus artificial diet (Table 2) (Silva et al., 2009).

Anagasta kuehniella, Diatraea saccharalis (Fabricius) (Lepidoptera: Pyralidae) and Spodoptera frugiperda (J. E. Smith) (Lepidoptera: Noctuidae) eggs were supplied ad libitum in $50 \mathrm{~mL}$ plastic vials covered with transparent lids, according to the treatment (Table 1). Newly-hatched larvae of $S$. frugiperda were similarly supplied to this predator, but with 20,30, 50 and 70 larvae for the first, second, third or fourth instars of E. connexa, respectively. Non-consumed prey were disposed and the consumption rate calculated.

Rearing cages for E. connexa larvae in the treatment with nymphs of Schizaphis graminum (Rondani) (Hemiptera:
Table 1. Food supplied to Eriopis connexa (Germar) (Coleoptera: Coccinellidae) larvae at $25 \pm 1{ }^{\circ} \mathrm{C}, 70 \pm 10 \%$ relative humidity and 12-hour photophase in Sete Lagoas, Minas Gerais State, Brazil.

\begin{tabular}{cl}
\hline Treatments & \multicolumn{1}{c}{ Diets } \\
\hline T1 & $\begin{array}{l}\text { Eggs of Anagasta kuehniella (frozen for } \\
\text { one day) }\end{array}$ \\
T2 & $\begin{array}{l}\text { Eggs of Spodoptera frugiperda (frozen } \\
\text { for one day) }\end{array}$ \\
T3 & Eggs fresh of Diatraea saccharalis \\
T4 & Spodoptera frugiperda newly-hatched \\
& larvae \\
T5 & Nymphs of Schizaphis graminum \\
T6 & Nymphs of Rhopalosiphum maidis \\
\hline
\end{tabular}

Table 2. Artificial diet for feeding of Eriopis connexa (Germar) (Coleoptera: Coccinellidae) at $25 \pm 1{ }^{\circ} \mathrm{C}$, $70 \pm 10 \%$ relative humidity and 12 hour-photophase in Sete Lagoas, Minas Gerais State, Brazil.

\begin{tabular}{lc}
\hline \multicolumn{1}{c}{ Compound } & Amount $(\mathbf{g})$ \\
\hline Honey & 100 \\
Brewer's yeast & 90 \\
FeSO4 & 1.5 \\
Ascorbic acid & 1.5 \\
Propionic acid & 0.50 \\
Sorbic acid & 0.25 \\
Nypagin & 0.25 \\
Water & 60 \\
\hline
\end{tabular}

Aphididae) and $R$. maidis were $50 \mathrm{ml}$ plastic cups with a paper filter moistened in $2 \mathrm{~mL}$ of water, $2 \mathrm{~cm}^{2}$ sections leaves of S. bicolor BRS 310 and nymphs until the third instar of these aphids ad libitum. These cages were sealed with transparent covers where E. connexa larvae remained until the adult emergence of the predator.

Eriopis connexa adults were sexed, body weight obtained just after emergence and transferred to cages (glass recipient $12 \mathrm{~cm}$ diameter and $18 \mathrm{~cm}$ height) closed with plastic wrap (PVC) and fed according to treatment.

The period of larva hatching to adult emergence of E. connexa was daily analysed to determine the number $(n=20)$, duration $(n=20)$ and survival $(n=40)$ of instars and of the prepupa, pupa and larva to adult stages and adult weight and sex ratio $(n=40)$ of this predator. All larvae of the treatment with $R$. maidis were used to obtain the parameters described, due to the low number of replications in this treatment $(n=20)$.

Data were submitted to variance analysis (ANOVA) and compared using the Tukey test at $5 \%$ probability (Russel, 1989).

\section{Results}

Eriopis connexa had four instars, in all treatments. Duration instars and the larva stage of E. connexa differed 
Table 3. Duration (days) of each instar and larval stage (mean \pm standard error) of Eriopis connexa (Germar) (Coleoptera: Coccinellidae) fed on different prey at $25 \pm 1{ }^{\circ} \mathrm{C}, 70 \pm 10 \%$ relative humidity and 12 hour-photophase in Sete Lagoas, Minas Gerais State, Brazil.

\begin{tabular}{cccccc}
\hline Treatments & First & Second & Third & Fourth & Larval phase \\
\hline T1 & $3.3 \pm 0.09^{\mathrm{a}}$ & $2.9 \pm 0.25^{\mathrm{a}}$ & $2.7 \pm 0.17^{\mathrm{ab}}$ & $3.6 \pm 0.12^{\mathrm{ab}}$ & $12.5 \pm 0.4^{\mathrm{a}}$ \\
T2 & $3.4 \pm 0.12^{\mathrm{a}}$ & $2.2 \pm 0.00^{\mathrm{bc}}$ & $2.4 \pm 0.08^{\mathrm{ab}}$ & $3.2 \pm 0.17^{\mathrm{bc}}$ & $11.2 \pm 0.2^{\mathrm{b}}$ \\
T3 & $2.5 \pm 0.05^{\mathrm{b}}$ & $2.5 \pm 0.05^{\mathrm{ab}}$ & $2.8 \pm 0.05^{\mathrm{ab}}$ & $2.8 \pm 0.05^{\mathrm{a}}$ & $10.6 \pm 0.1^{\mathrm{bc}}$ \\
T4 & $3.2 \pm 0.08^{\mathrm{a}}$ & $2.8 \pm 0.19^{\mathrm{a}}$ & $2.9 \pm 0.27^{\mathrm{a}}$ & $3.9 \pm 0.18^{\mathrm{a}}$ & $12.8 \pm 0.4^{\mathrm{a}}$ \\
T5 & $2.4 \pm 0.08^{\mathrm{a}}$ & $2.4 \pm 0.05^{\mathrm{a}}$ & $2.2 \pm 0.09^{\mathrm{ab}}$ & $2.8 \pm 0.09^{\mathrm{a}}$ & $9.8 \pm 0.2^{\mathrm{c}}$ \\
T6 & $2.1 \pm 0.06^{\mathrm{b}}$ & $1.9 \pm 0.05^{\mathrm{c}}$ & $2.0 \pm 0.00^{\mathrm{a}}$ & $2.5 \pm 0.17^{\mathrm{d}}$ & $8.5 \pm 0.2^{\mathrm{d}}$ \\
\hline
\end{tabular}

Means followed by the same letter, per column, do not differ by Tukey test $(\mathrm{p}<0.05)$.

between treatments (Table 3) but with similar values for this predator fed on eggs of $S$. frugiperda (T2) or D. saccharalis (T3) as well as with A. kuehniella and S. frugiperda newlyhatched larvae (T4) (Table 3).

Eriopis connexa consumed $28.0 \pm 5.5,55,8 \pm 5,2$, $125.7 \pm 9.9$ and $275.9 \pm 11.2$ newly-hatched larvae of $S$. frugiperda during the first, second, third and fourth instars, respectively, with total consumption of $485.4 \pm 14.8$ larvae of this prey, during the larva stage of this predator.

Duration of E. connexa prepupa stage was similar among treatments (Table 4). Survival of this stage was also similar between treatments, except for the lower survival with $S$. frugiperda newly-hatched larvae (Table 5).

Prey type affected the duration of E. connexa pupa stage, with variation from 3.1 to 3.7 days (Table 4), whereas pupa survival of E. connexa was similar between treatments (Table 5).

Duration of larva stage was shorter with nymphs of $R$. maidis (T6); 8.5 days (Table 3 ). The duration from larva to adult of $E$. connexa ranged from 12.6 to 17.2 days, differing among treatments (Table 4). The percentage of adult emergence of this predator was high in all treatments (>90\%) except with $S$. frugiperda newly-hatched larvae (Table 5).

The sex ratio of $E$. connexa was similar between treatments, whereas the weight of females of this predator was higher than males (Table 6).

\section{Discussion}

The number of E. connexa instars was the same as that of this predator fed on Coccinella undecimpunctata (L.) (Coleoptera: Coccinellidae), Megoura persicae (Buckton) and Aphis fabae (Scopoli) (Hemiptera: Aphididae) (Cabral et al., 2006); Diuraphis noxia (Mordvilko) and R. maidis, D. noxia, Acyrnothosiphon pisum (Harris) and Myzus persicae (Sulzer), Cinara atlantica (Wilson) (Hemiptera: Aphididae) (Miller and Paustian, 1992; Miller, 1995; Oliveira et al., 2004) and with Scymnus (Neopullus) sinuanodulus Yu and Yao (Coleoptera: Coccinellidae) (Lu et al., 2002). Generalist predators obtain better nutritional balance by including different sources to complement their diet (Roger et al., 2000; Snyder and Clevenger, 2004). Inadequate diets, generally, increase the number of instars (Scriber and
Table 4. Duration (days) of prepupa, pupa and larva for the adult period (mean \pm standard error) for Eriopis connexa (Germar) (Coleoptera: Coccinellidae) fed on different prey at $25 \pm 1{ }^{\circ} \mathrm{C}, 70 \pm 10 \%$ relative humidity and 12 hourphotophase in Sete Lagoas, Minas Gerais State, Brazil.

\begin{tabular}{cccc}
\hline Treatments & Prepupa & Pupa & Larva-adult \\
\hline T1 & $1.0 \pm 0.00^{\mathrm{a}}$ & $3.7 \pm 0.01^{\mathrm{a}}$ & $17.2 \pm 0.44^{\mathrm{ab}}$ \\
T2 & $1.1 \pm 0.10^{\mathrm{a}}$ & $3.7 \pm 0.18^{\mathrm{a}}$ & $16.0 \pm 0.11^{\mathrm{bc}}$ \\
T3 & $1.1 \pm 0.05^{\mathrm{a}}$ & $3.4 \pm 0.08^{\mathrm{ab}}$ & $15.1 \pm 0.09^{\mathrm{c}}$ \\
T4 & $1.0 \pm 0.00^{\mathrm{a}}$ & $3.6 \pm 0.06^{\mathrm{a}}$ & $17.4 \pm 0.30^{\mathrm{a}}$ \\
T5 & $1.0 \pm 0.00^{\mathrm{a}}$ & $3.6 \pm 0.06^{\mathrm{a}}$ & $14.4 \pm 0.26^{\mathrm{c}}$ \\
T6 & $1.0 \pm 0.00^{\mathrm{a}}$ & $3.1 \pm 0.06^{\mathrm{b}}$ & $12.6 \pm 0.23^{\mathrm{e}}$ \\
\hline
\end{tabular}

Means followed by the same letter, per column, do not differ by Tukey test $(\mathrm{p}<0.05)$.

Slansky, 1981; Thompson, 1999). Those supplied to E. connexa were of good quality, since this predator had the same number of instars with all of them and the prey type is important for the maintenance of its number of predatory insects (Nava and Parra, 2005; Phoofolo et al., 2007, 2009; Silva et al., 2009).

The larvae period of E. connexa fed on S. graminum (T5) had a similar duration to those obtained with $D$. saccharalis. This predator fed on R. maidis nymphs (T6) had a shorter larva stage than with other diets. The longer duration of first and fourth instars of E. connexa suggest the need for nutrient storage of this predator in these instars (Scriber and Slansky, 1981; Thompson, 1999). The longer duration of the fourth instar was also found for Pseudodorus clavatus (Fabricius) (Diptera: Syrphidae) fed on $S$. graminum, which is interesting since there is higher predation rate in this instar (Auad, 2003).

The consumption increase from newly-hatched larvae to last instars of E. connexa corroborates data for Propylea dissecta (Mulsant) (Coleoptera: Coccinellidae) showing that neonate larvae of Coccinellidae have lower foraging ability (Hemptinne et al., 1992), consumption rate (Ponsonby and Copland, 2000) and voracity (Pervez and Omkar, 2004), perhaps due to the small size and mobility of initial instars of the predator.

The higher consumption of $S$. frugiperda larvae by fourth instar larvae of $E$. connexa may indicate the necessity of nutrients for pupation as showed for Rhyzobius lophanthae 
Table 5. Survival (\%) of larva, prepupa, pupa and larva to adult periods (mean \pm standard error) for Eriopis connexa (Germar) (Coleoptera: Coccinellidae) fed on different prey at $25 \pm 1^{\circ} \mathrm{C}, 70 \pm 10 \%$ relative humidity and 12 hour-photophase in Sete Lagoas, Minas Gerais State, Brazil.

\begin{tabular}{crrrc}
\hline Treatments & Larva & Prepupa & \multicolumn{1}{c}{ Pupa } & Larva-adult \\
\hline T1 & $92.5 \pm 4.8^{\mathrm{a}}$ & $100.0 \pm 0.0^{\mathrm{a}}$ & $100.0 \pm 0.0^{\mathrm{a}}$ & $92.5 \pm 4.8^{\mathrm{a}}$ \\
T2 & $95.0 \pm 4.8^{\mathrm{a}}$ & $97.5 \pm 2.5^{\mathrm{a}}$ & $95.0 \pm 2.9^{\mathrm{a}}$ & $92.5 \pm 4.8^{\mathrm{a}}$ \\
T3 & $100.0 \pm 0.0^{\mathrm{a}}$ & $90.0 \pm 4.1^{\mathrm{a}}$ & $100.0 \pm 0.0^{\mathrm{a}}$ & $90.0 \pm 4.1^{\mathrm{a}}$ \\
T4 & $57.5 \pm 8.5^{\mathrm{b}}$ & $76.0 \pm 5.8^{\mathrm{b}}$ & $87.5 \pm 7.9^{\mathrm{a}}$ & $37.5 \pm 7.5^{\mathrm{b}}$ \\
T5 & $100.0 \pm 0.0^{\mathrm{a}}$ & $97.5 \pm 2.5^{\mathrm{a}}$ & $100.0 \pm 0.0^{\mathrm{a}}$ & $97.5 \pm 2.5^{\mathrm{a}}$ \\
T6 & $100.0 \pm 0.0^{\mathrm{a}}$ & $100.0 \pm 0.0^{\mathrm{a}}$ & $95.0 \pm 0.0^{\mathrm{a}}$ & $95.0 \pm 2.9^{\mathrm{a}}$ \\
\hline
\end{tabular}

Means followed by the same letter, per column, do not differ by Tukey test $(\mathrm{p}<0.05)$.

Table 6. Adult sex rate (\%) and weight (mg) (mean \pm standard error) of Eriopis connexa (Germar) (Coleoptera: Coccinellidae) from larvae fed on different prey at $25 \pm 1{ }^{\circ} \mathrm{C}, 70 \pm 10 \%$ relative humidity and 12 hourphotophase in Sete Lagoas, Minas Gerais State, Brazil.

\begin{tabular}{ccrc}
\hline \multirow{2}{*}{ Treatments } & \multirow{2}{*}{\begin{tabular}{c} 
Sex ratio \\
\cline { 3 - 4 }
\end{tabular}} & \multicolumn{2}{c}{ Weight $(\mathbf{m g})$} \\
\cline { 3 - 4 } T1 & $0.48 \pm 0.05^{\mathrm{a}}$ & $11.0 \pm 0.56^{\mathrm{b}}$ & $7.0 \pm 0.26^{\mathrm{c}}$ \\
T2 & $0.48 \pm 0.04^{\mathrm{a}}$ & $10.9 \pm 0.20^{\mathrm{b}}$ & $7.7 \pm 0.17^{\mathrm{bc}}$ \\
T3 & $0.53 \pm 0.04^{\mathrm{a}}$ & $12.4 \pm 0.08^{\mathrm{a}}$ & $7.9 \pm 0.07^{\mathrm{a}}$ \\
T4 & $0.62 \pm 0.13^{\mathrm{a}}$ & $8.6 \pm 0.12^{\mathrm{c}}$ & $5.1 \pm 0.20^{\mathrm{d}}$ \\
T5 & $0.61 \pm 0.05^{\mathrm{a}}$ & $13.3 \pm 0.04^{\mathrm{a}}$ & $8.9 \pm 0.07^{\mathrm{a}}$ \\
T6 & $0.52 \pm 0.05^{\mathrm{a}}$ & $13.2 \pm 0.11^{\mathrm{a}}$ & $8.9 \pm 0.06^{\mathrm{a}}$ \\
\hline
\end{tabular}

Means followed by the same letter, per column, do not differ by Tukey test $(\mathrm{p}<0.05)$.

(Blaisdell) (Coleoptera: Coccinellidae) fed on Parlatoria pergandii Comstock (Hemiptera: Diaspididae) (Stathas, 2000) and growth and development (Sharma et al., 1997). The food consumption increasing in the fourth instar Coccinellidae also shows food suitability, because the size of larvae of the last instar determines that of the adult (Phoofolo et al., 2007, 2009; Honek et al., 2008).

Duration of E. connexa larva stage with eggs of A. kuehniella, D. saccharalis or eggs or newly-hatched larvae of $S$. frugiperda was similar to that reported for E. connexa with C. atlantica (Oliveira et al., 2004), whereas those obtained with nymphs of $S$. graminum and $R$. maidis had similar values to those with $D$. noxia and $R$. padi (Miller and Paustian, 1992) and with D. noxia, A. pisum and M. persicae (Miller, 1995). Survival of E. connexa larva stage was similar between treatments, as reported for this predator with $D$. noxia and $R$. padi (Miller and Paustian, 1992) and M. persicae and D. noxia (Miller, 1995), respectively, except for the lower survival in the treatment with $S$. frugiperda newly-hatched larvae.

The similar duration of the prepupa stage between treatments shows that prey were adequate for E. connexa, because inadequate resources for growth and development can compromise insect development (Scriber and Slansky, 1981; Thompson, 1999; Michaud and Jyoti, 2007). Duration of prepupa was similar to that of $C$. sanguinea with M. persicae, Megoura viciae (Buckton), Aphis gossypii (Glover) and Aphis fabae (Scopoli) (Hemiptera:
Aphididae) (Isikber and Copland, 2002). Prepupa behaviour of $E$. connexa differed from of $S$. sinvanodulus, because it released fluids from the anal region in great quantity when its larvae stopped feeding and became static for one to two days (Lu et al., 2002). This was also observed for E. connexa, but is not recorded for $S$. sinvanodulus larvae (Lu et al., 2002), which, after the period of immobility, crawled and formed the pupa afterwards. However, a high percentage of $S$. sinvanodulus pupa with this behaviour died (Lu and Montgomery, 2001; Lu et al., 2002). The crawling of $S$. sinvanodulus larvae was associated to a mechanism for dispersion and seeking adequate sites for feeding and pupation (Lu et al., 2002).

The duration of pupa stages with $D$. saccharalis eggs (T3) was similar to those of other treatments, whereas no differences were found with nymphs of $R$. maidis (T6) or $D$. saccharalis eggs, being of 3.1 and 3.4 days, respectively. This was similar to that of this predator with $D$. noxia and R. padi (Miller and Paustian, 1992). The shorter duration of the pupa stage with fresh eggs of $D$. saccharalis (T3) and nymphs of $R$. maidis (T6) is important, because the pupa is almost static and longer duration of this stage can increase of predation and parasitism. On the other hand, increasing duration of this stage in the other treatments can be beneficial for pupa storage in mass rearing procedures, to wait for more appropriate periods for their release for pest control (Auad, 2003). Viability of E. connexa pupa was similar to that of this predator with C. atlantica (Oliveira et al., 2004), D. noxia and R. padi (Miller and Paustian, 1992; Miller, $1995)$. High pupa survival of $E$. connexa, in all treatments, suggests that prey tested supplied the metabolic needs of this predator in the previous stages. This is important because prey type affects fertility and other biological features of predators (Ferkovich et al., 2007).

The shorter duration from larva to adult of E. connexa with $R$. maidis suggests better nutritional quality for this aphid, since inadequate food can extend the life cycle of insects (Scriber and Slansky, 1981; Thompson, 1999). The development period of Coccinellidae can be higher with poor nutritional quality diets or with unsatisfactory quantity (Michaud and Jyoti, 2007). In addition, the lack of some nutrients such as aminoacids may increase the duration of the immature stage of insects (Hacker and Bertness, 1996; Bottrell et al., 1998). Our findings suggest that aphidophagous Coccinellidae develop more rapidly when fed on aphids than with other prey, as also reported for C. maculata (Michaud and Jyoti, 2007). 
The similar sex ratio of E. connexa fed on different prey agrees with the finding for this predator with M. persicae, D. noxia and A. pisum (Miller 1995) or C. atlantica (Oliveira et al., 2004), for Diomus austrinus (Gordon) (Coleoptera: Coccinellidae) with Phenacocus madeirensis (Green) and Planococus citri (Risso) (Hemiptera: Pseudococcidae) (Chong et al., 2005), and for Stethorus punctillum (Weise) (Coleoptera: Coccinellidae) (Heimpel and Lundgren, 2000). The negative rate between duration of larva stage and adult weight of Coccinellidae is known (Michaud and Jyoti, 2007) as for E. connexa, with shorter development period and higher weight with $R$. maidis and $S$. graminum. Eriopis connexa females were heavier with nymphs of $S$. graminum and $R$. maidis (T5 and T6), which is desirable for mass rearing, because heavier females can produce more descendents (Zanuncio et al., 2002, Omkar and Srivastava, 2003).

The weight of E. connexa adults can be used as sex dimorphism, because females were always heavier than males, as reported for Coccinella septempunctata $\mathrm{L}$. (Coleoptera: Coccinellidae) and H. convergens with Myzus persicae nicotianae (Sulzer) (Hemiptera: Aphididae) (Katsarou et al., 2005).

High survival of immature stages and heavier weight of E. connexa, in all treatments, except with $S$. frugiperda newly-hatched larvae, corroborates the polyphagous feeding habit of this predator. This shows its feeding plasticity and ability to adapt to different diets, which is interesting for the management of corn and sorghum pests and evidences its potential for biological control. Our results were relevant, but the potential of E. connexa in biological control programmes needs to be better studied in the field. This predator is not common in corn and sorghum crops, and that is why further studies are necessary to assess its adaptation and role in these crops. This can contribute to correct releasing and improving efficiency, and to reducing problems, such as intraguild predation and competition that can compromise native natural enemies of insect pests in these crops.

Acknowledgements - This work was supported by the Coordenação de Aperfeiçoamento de Pessoal de Nível Superior (CAPES), the Conselho Nacional de Desenvolvimento Científico e Tecnológico (CNPq) and the Fundação de Amparo à Pesquisa do Estado de Minas Gerais (FAPEMIG).

\section{References}

AUAD, AM., 2003. Biological aspects of the immature stages of Pseudodorus clavatus (Fabricius) (Diptera: Syrphidae) fed on Schizaphis graminum (Rondani) (Hemiptera: Aphididae) at different temperatures. Neotropical Entomology, vol. 2, p. 475-480.

BERKVENS, N., BONTE, L., BERKVENS, D., TIRRY, L. and DE CLERCQ, P., 2008. Influence of diet and photoperiod on development and reproduction of European populations of Harmonia axyridis (Pallas) (Coleoptera: Coccinellidae). BioControl, vol. 53, p. 211-221. http://dx.doi.org/10.1007/s10526-007-9130-0

BOTTRELL, DG., BARBOSA, P. and GOULD, F., 1998. Manipulating natural enemies by plant variety selection and modification: a realistic strategy? Annual Review of Entomology, vol. 43, p. 347-367. PMid:15012394. http://dx.doi.org/10.1146/ annurev.ento.43.1.347

CABRAL, S., SOARES, AO., MOURA, R. and GARCIA, P., 2006. Suitability of Aphis fabae, Myzus persicae (Homoptera:
Aphididae) as prey for Coccinella undecimpunctata (Coleoptera: Coccinellidae). BioControl, vol. 39, p. 434-440.

CHONG, JH., OETTING, RD. and OSBORNE, LS., 2005. Development of Diomus austrinus Gordon (Coleoptera: Coccinellidae) on two mealybug prey species at five constant temperatures. Biological Control, vol. 33, p. 39-48. http://dx.doi. org/10.1016/j.biocontrol.2005.01.005

CRUZ, I., REDOAN, AC., SILVA, RB., FIGUEIREDO, MLC. and PENTEADO-DIAS, AM., 2011. New record of Tetrastichus howardi (Olliff) as a parasitoid of Diatraea saccharalis (Fabr.) on maize. Scientia Agricola, vol. 68, p. 252-254. http://dx.doi. org/10.1590/S0103-90162011000200017

EUBANKS, MD. and DENNO, RF., 2000. Health food versus fast food: the effects of prey quality and mobility on prey selection by a generalist predator and interactions among prey species. Ecological Entomology, vol. 25, p. 140-146. http://dx.doi. org/10.1046/j.1365-2311.2000.00243.x

FERKOVICH, SM., VENKATESAN, T., SHAPIRO, JP. and CARPENTER, JE., 2007. Presentation of artificial diet: effects of composition and size of prey and diet domes on egg production by Orius insidiosus (Heteroptera: Anthocoridae). Florida Entomologist, vol. 90, p. 502-508. http://dx.doi.org/10.1653/00154040(2007)90[502:POADEO]2.0.CO;2

FIGUEIREDO, MLC., MARTINS-DIAS, AMP. and CRUZ, I., 2006a. Exasticolus fuscicornis associated to larva of Spodoptera frugiperda. Pesquisa Agropecuária Brasileira, vol. 41, p. 13211323. http://dx.doi.org/10.1590/S0100-204X2006000800016

-, 2006b. Relationship between fall armyworm and their natural biological control agents in the maize crop. Pesquisa Agropecuária Brasileira, vol. 41, p. 1693-1698.

HACKER, SD. and BERTNESS, MD., 1996. Throphic consequences of a positive plant interaction. The American Naturalist, vol. 148, p. 559-575. http://dx.doi.org/10.1086/285939

HEIMPEL, GE. and LUNDGREN, JG., 2000. Sex ratios of commercially reared biological control agents. Biological Control, vol. 19, p. 77-93. http://dx.doi.org/10.1006/bcon.2000.0849

HEMPTINNE, JL., DIXON, AFG. and COFFIN, J., 1992. Attack strategy of ladybird beetles (Coccinellidae) factors shaping their numerical response. Oecologia, vol. 90, p. 238-245.

HONEK, A., DIXON, AFG. and MARTNKOVA, Z., 2008. Body size, reproductive allocation, and maximum reproductive rate of two species of aphidophagous Coccinellidae exploiting the same resource. Entomologia Experimentalis et Applicata, vol. 127, p. 1-9. http://dx.doi.org/10.1111/j.1570-7458.2007.00663.x

ISIKBER, AA. and COPLAND, MJW., 2002. Effects of various aphid foods on Cycloneda sanguinea. Entomologia Experimentalis et Applicata, vol. 102, p. 93-97. http://dx.doi.org/10.1046/j.15707458.2002.00928.x

KATSAROU, I., MARGARITOPOULOS, JT., TSITSIPIS, JA., PERDIKIS, DC. and ZARPAS, KD., 2005. Effect of temperature on development, growth and feeding of Coccinella septempunctata and Hippodamia convergens reared on the tobacco aphid, Myzus persicae nicotianae. BioControl, vol. 50, p. 565-588. http://dx.doi. org/10.1007/s10526-004-2838-1

LU, W. and MONTGOMERY, ME., 2001. Oviposition, development, and feeding of Scymnus (Neopullus) sinuanodulus (Coleoptera: Coccinellidae): a predator of Adelges tsugae (Homoptera: Adelgidae). Annals of the Entomological Society of America, vol. 94, p. 6470. http://dx.doi.org/10.1603/0013-8746(2001)094[0064:ODA FOS]2.0.CO;2 
LU, W., SOUPHANY, P. and MONTGOMERY, ME., 2002. Descriptions of immature stages of Scymnus (Neopullus) sinuanodulus Yu and Yao (Coleoptera: Coccinellidae) with notes on life history. The Coleopterist Bulletin, vol. 56, p. 127-141. http://dx.doi. org/10.1649/0010-065X(2002)056[0127:DOISOS]2.0.CO;2

MICHAUD, JP. and JYOTI, JL., 2007. Dietary complementation across life stages in the polyphagous lady beetle Coleomegilla maculata. Entomologia Experimentalis et Applicata, vol. 126, p. $40-45$

MILLER, JC., 1995. A comparison of techniques for laboratory propagation of a South American ladybeetle, Eriopis connexa (Coleoptera: Coccinellidae). Biological Control, vol. 5, p. 462465. http://dx.doi.org/10.1006/bcon.1995.1055

MILLER, JC. and PAUSTIAN, JW., 1992. Temperature-dependent development of Eriopis connexa (Coleoptera: Coccinellidae). Environmental Entomology, vol. 21, p. 1139-1142.

NAVA, DE. and PARRA, JRP., 2005. Biology of Stenoma catenifer Walsingham (Lepidoptera: Elachistidae) in natural and artificial diets and development of a rearing system. Neotropical Entomology, vol. 34, p. 751-759. http://dx.doi.org/10.1590/ S1519-566X2005000500006

OLIVEIRA, NC., WILCKEN, CF. and MATOS, CAO., 2004. Biological cycle and predation of three coccinellid species (Coleoptera, Coccinellidae) on giant conifer aphid Cinara atlantica (Wilson) (Hemiptera, Aphididae). Revista Brasileira de Entomologia, vol. 48, p. 529-533. http://dx.doi.org/10.1590/ S0085-56262004000400016

OMKAR and SRIVASTAVA, S., 2003. Influence of six aphid prey species on development and reproduction of ladybird beetle, Coccinella septempunctata. BioControl, vol. 48, p. 379-393. http://dx.doi.org/10.1023/A:1024762822955

PERVEZ, A. and OMKAR, 2004. Prey-dependent life attributes of an aphidophagous ladybird beetle, Propylea dissecta (Coleoptera: Coccinellidae). Biocontrol Science and Technology, vol. 14, p. 385-396. http://dx.doi.org/10.1080/09583150410001683547

PHOOFOLO, MW., GILES, KL. and ELLIOTT, NC., 2007. Quantitative evaluation of suitability of the greenbug, Schizaphis graminum, and the bird cherry-oat aphid, Rhopalosiphum padi, as prey for Hippodamia convergens (Coleoptera: Coccinellidae). Biological Control, vol. 41, p. 25-32. http://dx.doi.org/10.1016/j. biocontrol.2006.12.017

PHOOFOLO, MW., ELLIOTT, NC. and GILES, KL., 2009. Analysis of growth and development in the final instar of three species of predatory Coccinellidae under varying prey availability. Entomologia Experimentalis et Applicata, vol. 131, p. 264-277. http://dx.doi.org/10.1111/j.1570-7458.2009.00849.x

PONSONBY, DJ. and COPLAND, MJW., 2000. Maximum feeding potential of larvae and adults of the scale insect predator, Chilocorus nigritus with a new method of estimating food intake. BioControl, vol. 45, p. 295-310. http://dx.doi.org/10.1023/A:1009953005065

ROGER, C., CODERRE, D. and BOIVIN, G., 2000. Differential prey utilization by the generalist predator according to prey size and species. Entomologia Experimentalis et Applicata, vol. 94, p. 3-13. http://dx.doi.org/10.1046/j.1570-7458.2000.00598.x

RUSSEL, DF., 1989. MSTAT-C Statistical Package Program. ver. 2.1. Michigan State University.

SARMENTO, RA., OLIVEIRA, HG., HOLTZ, AM., SILVA, SM., SERRÃO, JE. and PALLINI, A., 2004. Fat body morphology of Eriopis connexa (Coleoptera: Coccinellidae) in function of two alimentary sources. Brazilian Archives of Biology and Technology, vol. 47, p. 407-411. http://dx.doi.org/10.1590/ S1516-89132004000300011
SARMENTO, RA., PALLINI, A., VENZON, M., SOUZA, OF., MOLINA-RUGAMA, AJ. and OLIVEIRA, CL., 2007. Functional response of the predator Eriopis connexa (Coleoptera: Coccinellidae) to different prey types. Brazilian Archives of Biology and Technology, vol. 50, p. 121-126. http://dx.doi.org/10.1590/ S1516-89132007000100014

SCRIBER, JM. and SLANSKY, FJ., 1981. The nutritional ecology of immature insects. Annual Review of Entomology, vol. 26, p. 183211. http://dx.doi.org/10.1146/annurev.en.26.010181.001151

SERTKAYA, E., BAYRAM, A. and KORNOSOR, S., 2004. Egg and larval parasitoids of the beet armyworm Spodoptera exigua on maize in Turkey. Phytoparasitica, vol. 32, p. 305-312. http:// dx.doi.org/10.1007/BF02979825

SHARMA, DK., VARMA, GC. and KISHORE, L., 1997. Feeding capacity of predators of mustard aphid, Lipaphis erysimi. Journal of Aphidology, vol. 11, p. 171-174

SILVA, RB., ZANUNCIO, JC., SERRÃO, JE., LIMA, ER., FIGUEIREDO, MLC. and CRUZ, I. 2009. Suitability of different artificial diets for development and survival of stages of predaceous ladybird beetle Eriopis connexa (Coleoptera: Coccinellidae). Phytoparasitica, vol. 37, p. 115-123. http://dx.doi.org/10.1007/ s12600-008-0015-2

SILVA, RB., CRUZ, I., FIGUEIREDO, MLC. and TAVARES, WS., 2010. Development of Coleomegilla maculata De Geer (Coleoptera: Coccinellidae) with prey and artificial diet. Revista Brasileira de Milho e Sorgo, vol. 9, p. 13-26.

SILVA, RB., CRUZ, I., FIGUEIREDO, MLC, PEREIRA, AG. and PENTEADO-DIAS, AM., 2012. Occurrence and biology of Dinocampus coccinellae (Schrank, 1802) (Hymenoptera; Braconidae: Euphorinae) parasitizing different species of Coccinellidae (Coleoptera) in Neotropical region. Brazilian Journal of Biology, vol. 72, p. 215-219. PMid:22437405. http://dx.doi.org/10.1590/ S1519-69842012000100027

SNYDER, WE. and CLEVENGER, GM., 2004. Negative dietary effects of Colorado potato beetle eggs for the larvae of native and introduced ladybird beetles. Biological Control, vol. 31, p. 353-361. http://dx.doi.org/10.1016/j.biocontrol.2004.05.003

SOARES, AO., CODERRE, D. and SCHANDERL, H., 2004. Dietary self-selection behaviour by the adults of the aphidophagous ladybeetle Harmonia axyridis (Coleoptera: Coccinellidae). Journal of Animal Ecology, vol. 73, p. 478-486. http://dx.doi. org/10.1111/j.0021-8790.2004.00822.x

-, 2005. Influence of prey quality on the fitness of two phenotypes of Harmonia axyridis adults. Entomologia Experimentalis et Applicata, vol. 114, p. 227-232. http://dx.doi.org/10.1111/j.15707458.2005.00246.x

STATHAS, GJ., 2000. Rhyzobius lophanthae prey consumption and fecundity. Phytoparasitica, vol. 28, p. 203-211. http://dx.doi. org/10.1007/BF02981798

THOMPSON, SN., 1999. Nutrition and culture of entomophagus insects. Annual Review of Entomology, vol. 44, p. 561-592. PMid:15012382. http://dx.doi.org/10.1146/annurev.ento.44.1.561

ZANUNCIO, JC., MOLINA-RUGAMA, AJ., SANTOS, GP. and RAMALHO, FS., 2002. Effect of body weight on fecundity and longevity of the stinkbug predator Podisus rostralis. Pesquisa Agropecuária Brasileira, vol. 37, p. 1225-1230. http://dx.doi. org/10.1590/S0100-204X2002000900004 